\title{
MAINTAINING THE COMPETITIVENESS OF THE CZECH RAILWAY INDUSTRY
}

\author{
JAN VOGL*, MÁRIA JÁNEŠOVÁ \\ Czech Technical University in Prague, Faculty of Transportation Sciences, Konviktská 20, 11000 Prague 1, \\ Czech Republic \\ * corresponding author: vogljan@fd.cvut.cz
}

\begin{abstract}
The development of foreign trade plays an important role in the Czech economy. The important foreign trade commodity item is Machinery and transport equipment (SITC 7). Railway vehicles is a part of this category, other means of transport (SITC 79).

In order to maintain competitiveness and economic growth, it is necessary for the railway industry to intensify the innovation and the introducing of new technologies into production. One of the available options is a wider implementation of life cycle cost analysis, which enables to activate innovative efforts, as well as to improve technical and performance data.
\end{abstract}

KEYWORDS: Export, railway vehicles, LCC analysis, innovation.

\section{INTRODUCTION}

The Czech Republic is a traditional export industrial country. Therefore, the development of foreign trade plays an important role in our economy. Last year, exports from the Czech Republic grew by $3.6 \%$ to CZK 4563.3 billion. The largest volume of Czech exports has been realized in the long term within the European Union countries, such as Germany, France, Great Britain and Poland. In 2019, the share of exports to EU countries reached $83.6 \%$. In terms of commodity structure (SITC), Machinery and transport equipment (SITC 7) are traditionally dominant. Their share in total exports in 2019 was about $59 \%$. Compared to 2018 , it grew by $5.1 \%$ [1].

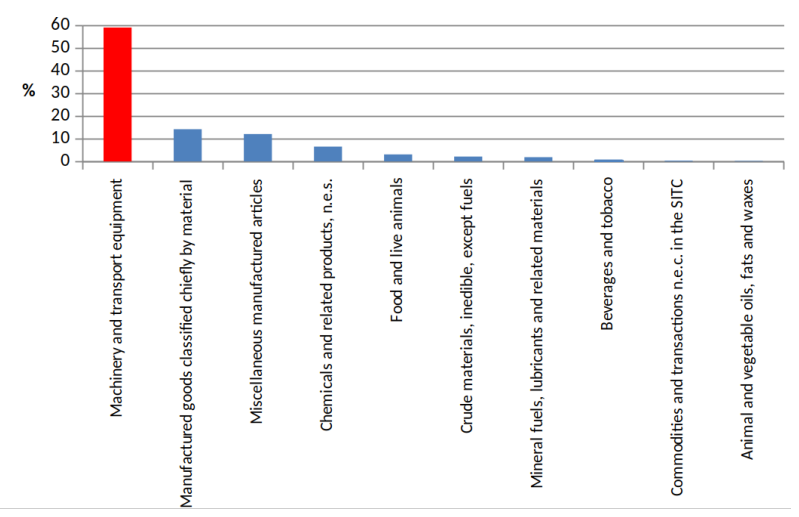

Figure 1. Cross-border movements of goods by commodities, year 2019, source: CZSO [1].

\section{Description of PRODUCT GROUP}

Railway vehicles is part of lager category, other transport equipment (SITC 79), which consists of:

- 791 Railway vehicles (including hovertrains) and associated equipment
- 792 Aircraft and associated equipment

- 793 Ships, boats and floating structures

If we focus on the export development in the commodity item Railway vehicles and related equipment (railway vehicles (including hovertrains) and associated equipment) we find out that in 2019 this item reached the value of CZK 20.5 billion. The largest volume of Czech exports of the mentioned commodity goes to Europe (approx. 88\%). These are, for example, deliveries of locomotives, metro trains, trams and components [1].

The published analysis of the Association of the Czech Railway Industry (ACRI) regarding the development of the Czech railway industry in 2012-2019 shows that 2015 was a turning point for the companies, which are the members of this association. In 2015, they have reached the highest turnover of 91 billion CZK. For example the total turnover in 2019 is about $16.5 \%$ lower in comparison with 2015 , as well as the total number of employees is lower by $6.5 \%$. Due to the global competition in foreign markets, Czech Railway Industry is not able to reach the successful year of 2015 up to now [2].

\section{InNOVATION AND LCC ANALYSiS}

In order to remain competitive on foreign markets, we need to increase the innovative potential of our products. The Czech Republic will not keep its significant competitive advantages of cheap labour for long time. According to a study by the European Commission entitled "Country-specific recommendations 2020 Research and Innovation analysis", the Czech Republic lags behind in the field of research and innovation within the EU. Productivity growth is mostly driven by large foreign companies, while domestic companies are lagging behind. The same applies to the growth of expenditure on research and development [3]. 


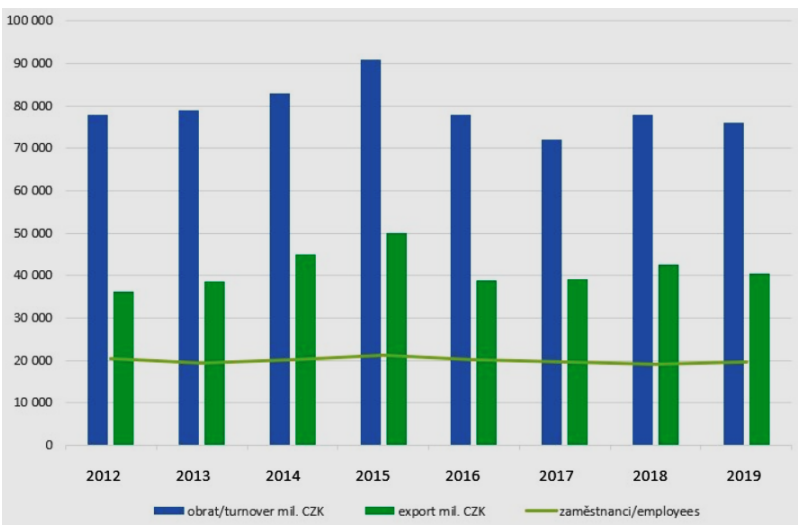

FiguRE 2. Exports of railway vehicles (including hovertrains) and associated equipment, source: ACRI 2].

The annual analysis of the European Commission "European Innovation Scoreboard 2020" showed that the Czech Republic was, according to the results of 27 indicators included in the Moderate Innovators 4 .

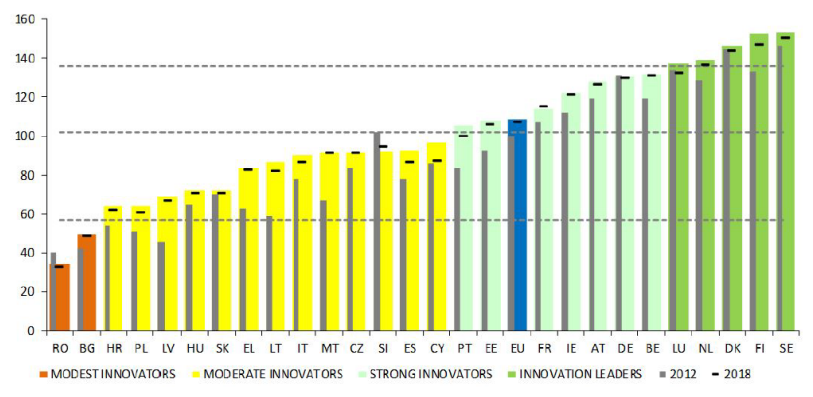

Figure 3. Performance of EU Member States' innovation systems, source: EU [4].

Innovation of the offered products is a key task for maintaining the competitiveness of manufacturing companies in the market. This can be achieved through innovation and close cooperation between companies and research institutions in research and development. The introduction of new technologies and innovations is important for the further successful economic growth of Czech industry. Efficient use of Life Cycle Cost (LCC) analysis contributes to this growth. The aim of LCC analysis is to determine the total cost of a product throughout its life cycle [5].

The results of my research among leading manufacturer of railway vehicles have shown that LCC analysis is one of those methods that has the ability to help increase innovation effects, the quality of the offered product and reduces overall costs. Furthermore, LCC analysis plays a significant contribution in tenders to select the railway vehicles.

\section{Conclusion}

The increasing use of the LCC analysis should be an important incentive for manufacturers to improve the reliability and quality of their products. The implementation of the LCC analysis will lead to innovative efforts and thus increase the competitiveness of the company. In the rail sector, where railway vehicles has been in operation for more than 30 years [6], operators can, together with manufacturers, optimize the total cost of ownership, which accounts for the largest share of the total LCC cost by railway vehicles [5]. Based on university research conducted in 2019-2020 with leading manufacturer of railway vehicles, it turned out that the use of LCC analysis not only reduces overall costs, but also activates innovation.

As the Czech industry is dependent on the export of its products to foreign markets, it is necessary not only in the railway industry, which has a two-hundred-year tradition, to capture new trends in the autonomous control, alternative drives or intelligent transport systems [7. This requires intensive and consistent cooperation with the government, research institutions, high-tech companies, but also other sectors such as energy and information and communication technologies. One of the approved government strategic framework plans is the Innovation Strategy of the Czech Republic 2019-2030, which aims to help move the Czech Republic among the most innovative countries in Europe within a few years. If we manage to capture new world trends in this sector, the Czech Republic will continue the economical grow and the improving of the quality of offered products and services to our citizens.

\section{REFERENCES}

[1] Český statistický úřad [ČSU]. Pohyb zboží přes hranice. In: Český statistický úřad. Databáze zahraničního obchodu v přeshraničním pojetí [online]. (O)2020. Available in: https:

//apl.czso.cz/pll/stazo/STAZO.STAZO?jazyk=EN

[2] Analýza Asociace podniků českého železničního průmyslu. In: ACRI [online]. Praha: Asociace podniků českého železničního průmyslu, 13. 5. 2020. Available in: https://acri.cz/2020/05/24/firmy-zeleznicnihoprumyslu-jsou-stabilnimi-tahouny-ceskeekonomiky-dokazuji-to-jejich-hospodarskevysledky-za-rok-2019/

[3] Country-specific recommendations 2020 - Research and Innovation analysis. [online]. European Commission. Brussel, 2020. Available in: https://rio.jrc.ec.europa.eu/library/2020country-specific-recommendations-research-andinnovation-analysis

[4] European Innovation Scoreboard 2020. [online]. European Commission. Brussel, 2020. Available in: https://ec.europa.eu/commission/presscorner/ detail/en/QANDA_20_115

[5] ČSN EN 60300-3-3. Management spolehlivosti - část 3-3: Pokyny použití - Analýza nákladů životního cyklu. Praha: Český normalizační institut, 2004. 60 s.

[6] Kontrolní závěr z kontrolní akce 17/35: Pořízení a obnova železničních kolejových vozidel. In: Nejvyšší kontrolní úřad [online]. Praha. Available in: https://www.nku.cz/assets/kon-zavery/K17035.pdf 
[7] Memorandum o budoucnosti českého železničního průmyslu. In: ACRI [online]. Praha, 2019. Available in: https://acri.cz/2019/04/12/memorandum-o-

budoucnosti-ceskeho-zeleznicniho-prumyslu/ 